\section{Genetic Alterations and Tumor Mutation Burden of Poorly Differentiated Small Cell Euro-endocrine Carcinomas are Similar in Lung Lesions and Distant Metastatic Foci}

\author{
Omid S Tehrani ${ }^{1 *}$, Philip J Stephens ${ }^{2}$, Garrett M Frampton ${ }^{3}$, Caitlin F Connelly ${ }^{3}$, Ethan S Sokol ${ }^{3}$, Jeffrey S Ross ${ }^{3}$, Vincent A Miller ${ }^{3}$ and Jackie Moriarty $^{3}$ \\ ${ }^{1}$ Department of Medicine-Oncology, Stanford University School of Medicine, Stanford, CA, USA \\ ${ }^{2}$ Department of Medicine-Oncology, Grail, Menlo Park, CA, USA \\ ${ }^{3}$ Department of Medicine-Oncology, Foundation Medicine, Cambridge, MA, USA
}

*Corresponding author: Omid S Tehrani, Department of Medicine-Oncology, Stanford University School of Medicine, Stanford, CA, USA, Tel: (408) 426-4900; E-mail: hematology123@gmail.com

Received date: Dec 01, 2018; Accepted date: December 21, 2018; Published date: December 24, 2018

Copyright: ( 2018 Tehrani OS, et al. This is an open-access article distributed under the terms of the Creative Commons Attribution License, which permits unrestricted use, distribution, and reproduction in any medium, provided the original author and source are credited.

\begin{abstract}
Objective: Studying the genetic alterations of poorly differentiated small cell neuroendocrine carcinomas to improve the understanding of the biology of these aggressive cancers.

Methods: Next generation sequencing was performed on the DNA extracted samples, using the Illumina HiSeq2000/4000 on 315 cancer related genes and tumor mutation burden was reported.

Results: In 914 small cell lung cancer (SCLC) and 115 small cell of undefined primary (SCUP), there were similar and close rates of genetic alterations in lung lesions and distant metastatic foci in SCLC and SCUP. Also, the majority of tumors, both lung lesions and distant metastatic foci, did not carry a high tumor mutation burden. Multiple potentially targetable driver genes were identified. Despite common involvement of transmembrane signaling pathways and transcription machinery, other than TP53 and RB1, there was no considerable concurrent gene alteration.
\end{abstract}

Conclusion: This study showed similar genetic alteration and tumor mutation burden in the lung lesions and in distant metastatic foci. TP53 and RB1 were the frequently altered concurrently.

Keywords: Small cell lung cancer; Oat cell; Neuroendocrine; Tumor mutation burden; Metastases; Mutation

\section{Introduction}

Neuroendocrine tumors are a wide array of different neoplasms arising from endocrine and nervous system origin. They commonly express chromogranin A, synaptophysin (p38), neural adhesion molecule (CD56), neuron-specific enolase, or neurofilament. They are generally categorized based on their degree of differentiation, grade and mitotic rate. Small cell poorly differentiated neuroendocrine carcinomas are small round blue cells with rapid proliferation rate, lack of structural formation, and poor differentiation. These cancers are aggressive, invade and metastasize early, respond to chemotherapy and radiation, and relapse almost universally. The most common type is the small cell lung cancer (SCLC), counting for $15 \%$ of lung cancers with higher incidence among older males with smoking history [1-6]. However, they can arise in many different organs and can be present in other cancers as well. Presence of a component of small cell neuroendocrine neoplasm in other tumors is associated with poor prognosis [7-9].

Multiple prior studies on small carcinoma cell lines, xenografts and primary human tumors have reported a variety of mutations, most commonly TP53 and RB1 [10-12]. These studies have shown variable genetic mutations in tumors arising from different organs. As an example, some have showed similar genetic alterations in small cell cancers arising in the pancreas and esophagus but showed different findings in those rare cancers originating in the bladder [13-15]. Similar mutational analysis leads to re-classification of small cell carcinoma of the ovaries as ovarian rhabdoid tumor [16]. Similarly, other studies have helped identify Merkel cell associate papilloma virus as a cause of this small cell poorly differentiated cancer of skin $[17,18]$. Understanding the altered genetic pathways in the tumors may help understand their biology, mechanisms involved in their development, their proper classification and potentially help with identifying therapeutic strategies. Previous studies with smaller sample size had shown limited co-occurrence of the genetic alterations and comparing genetic alterations in metastasis lesions in different organs [10,19-21]. In order to improve our understanding of the genes and pathways involved in these tumors, the current study compares mutations in a larger set of lung lesions, distant metastatic foci and small cell carcinoma of undefined primary (SCUP), and also evaluates cooccurrence of those mutations.

\section{Methods}

Genetic sequencing methods are fully explained in a previous publication [22]. Briefly, samples were diagnosed by local pathologist and then slides were submitted for hybrid capture based comprehensive genomic profiling (CGP) to Foundation Medicine (Cambridge, MA). Tumor samples analyzed between January 2010 to 
Citation: Tehrani OS, Stephens PJ, Frampton GM, Connelly CF, Sokol ES, et al. (2018) Genetic Alterations and Tumor Mutation Burden of Poorly Differentiated Small Cell Euro-endocrine Carcinomas are Similar in Lung Lesions and Distant Metastatic Foci. J Carcinog Mutagen 9: 328. doi:10.4172/2157-2518.1000328

Page 2 of 6

December 2016 was included. Origins of the primary tumor were based on the documented report by the requesting local institutions. Tumors without documented origin were classified as small cell carcinoma of undefined primary (SCUP). DNA was extracted from formaldehyde fixed paraffin embedded biopsy or surgical specimens. CGP was performed using the Illumina HiSeq2000/4000 on indexed, adaptor ligated, hybridization-captures libraries for exons of 315 cancer related genes and 47 introns of 19 genes frequently involved in rearrangements.

Genetic alterations included base substitutions, short insertions and deletions, amplifications, homologous deletions and chromosomal rearrangements. Alterations likely or known to be bona-fide oncogenic drivers and germ-line polymorphisms were included. Alterations were reported as short variants, copy number for genes (amplifications and losses), or rearrangements. Short variants include single-base nucleotide substitutions, small-scale multi-base deletions or insertions, and microsatellite repeats. Publicly available and validated analysis tools were used to analyze the data. Median exon unique coverage was 647X. For tumor mutation burden (TMB), the number of somatic mutations detected on NGS (interrogating 1.2 Mb of the genome) were quantified and that value extrapolated to the whole exome using a validated algorithm $[23,24]$. TMB was measured in mutations per mega base $(\mathrm{Mb})$ and was divided into three groups: low (1-5 mutations/Mb), intermediate (6-19 mutations/Mb), and high ( $\geq 20$ mutations/Mb). One hundred non-synonymous mutations per exome were used as a threshold. The threshold of 20 coding mutations per $\mathrm{Mb}$ was used as equivalent to 400 non-synonymous mutations per exome. In a large cohort of patients this approximately divided patients to $50 \%$ as low TMB, about $40 \%$ as intermediate TMB, and about $10 \%$ as high TMB [25]. Gene rearrangements were detected by identifying clusters of chimeric read pairs from both DNA (pairs mapping 0.10 kilo bases (kb) apart or on different chromosomes) and RNA (pairs mapping to RefSeq sequences corresponding to different genes or to genomic loci $0.10 \mathrm{~kb}$ apart). Chimera clusters were filtered for repetitive sequence and by distribution of mapped positions. Identified rearrangements were then annotated according to the genomic loci of both clusters and categorized as gene fusions, gene rearrangements, or truncating events. Throughout the study, cumulative de-identified data were extracted from data-bank, without access to the patients' data, was used. In agreement with Declaration of Helsinki, In addition to Independent Review Board (IRB) of the institutions sending the samples, Western IRB was used to obtain approval for our publication, including a waiver of informed consent and HIPAA waiver of authorization.

\section{Statistical methods}

Simple statistical methods were used to compare the frequency of mutations in different groups, to calculate odds ratios and $\mathrm{p}$-values by publicly available online calculator (https://www.medcalc.org/calc/ odds_ratio.php). The difference of TMB between the lung lesions and distant metastatic foci was calculated with $2 \times 3$ chi-square contingency test. Gene enrichment scores (ES) were calculated by a one tailed hyper-geometric test using publicly available online programs (http://systems.crump.ucla.edu/hypergeometric/index.php).

\section{Results}

Among all reported gene alterations, short variants were the most common alterations and rearrangements were the least common ones (Tables 1 and 2).

\section{Tissue of origin}

In total, 914 SCLC were identified, 406 as lung lesions, and 310 as SCLC distant metastatic foci, with 198 SCLC as ambiguous state (unknown site of biopsy). The most common site of biopsy of metastatic SCLC was the liver (205/310;58.9\%), followed by the brain (33/310; $9.5 \%)$, bone $(26 / 310 ; 7.5 \%)$, soft tissue $(24 / 310 ; 6.9 \%)$, adrenal glands $(21 / 310 ; 6 \%)$ and other organs $(40 / 310 ; 11 \%)$. One hundred fifteen (115) samples were categorized as SCUP.

\section{Gene alterations in SCLC}

The most common alterations (>4.5\%) included: TP53 (90.4\%) followed by RB1 (69.1\%), KMT2D (11.9\%), LRP1B (11.4\%), PTEN (8.3\%), MYCL (7.7\%), RICTOR (6.2\%), MYC (6\%), CREBBP (5.7\%), SPTA1 (5.5\%), FAT1 (5.3\%), PIK3CA (4.9\%). Findings are summarized in Table 1. Among the targetable genes in SCLC, PTEN alteration was seen in $8.3 \%$ and $R I C T O R$ amplification was observed in $6.1 \%$ of cases. EGFR alterations was seen in $3.5 \%, K I T 3 \%, B R C A 2$ $1.3 \%$, JAK2 $1.2 \%$, and $B R A F$ in $1 \%$ of cases. $E R B B 2$ alterations were reported in $4.3 \%$ (2.6\% short variant and $1.7 \%$ amplifications) were reported in SCLC. TERC mutation was reported in $1 \%$ of cases. There was also alteration detected in NOTCH1 4.7\%, NOTCH2 $2 \%$, NOTCH32\%, NOTCH4 1.6\%.

\begin{tabular}{|l|l|l|l|l|}
\hline Gene & All alterations & Short variant & Copy number & Rearrangement \\
\hline TP53 & $90.40 \%$ & $89.20 \%$ & $1.10 \%$ & $0.00 \%$ \\
\hline RB1 & $69.10 \%$ & $59.40 \%$ & $8.60 \%$ & $0.70 \%$ \\
\hline MLL2 & $11.90 \%$ & $11.40 \%$ & $0.00 \%$ & $0.40 \%$ \\
\hline LRP1B & $11.40 \%$ & $10.50 \%$ & $0.50 \%$ & $0.30 \%$ \\
\hline PTEN & $8.30 \%$ & $4.00 \%$ & $4.00 \%$ & $0.10 \%$ \\
\hline MYCL1 & $7.70 \%$ & $0.00 \%$ & $7.50 \%$ & $0.10 \%$ \\
\hline RICTOR & $6.20 \%$ & $0.10 \%$ & $6.10 \%$ & $0.00 \%$ \\
\hline MYC & $6.00 \%$ & $0.00 \%$ & $6.00 \%$ & $0.00 \%$ \\
\hline CREBBP & $5.70 \%$ & $4.90 \%$ & $0.60 \%$ & $0.20 \%$ \\
\hline SPTA1 & $5.50 \%$ & $5.30 \%$ & $0.00 \%$ & $0.10 \%$ \\
\hline FAT1 & $5.30 \%$ & $5.10 \%$ & $0.30 \%$ & $0.00 \%$ \\
\hline PIK3CA & $4.90 \%$ & $3.40 \%$ & $1.30 \%$ & $0.00 \%$ \\
\hline
\end{tabular}

Table 1: Common gene alterations in Small Cell Lung Cancer (SCLC).

\section{Gene alterations in SCUP}

Most common SCUP alterations ( $>4.5 \%)$ included: TP53 (78.3\%) followed by RB1 (62.6\%), PTEN (13.9\%), KRAS (9.6\%), CREBBP (7.8\%), APC (7.8\%), KMT2D (7\%), MYC (7\%), PIK3CA (6.1\%), MUTYH (5.3\%), LRP1B (4.3\%). Findings are summarized in Table 2. Among the targetable genes in SCUP, PTEN alteration was seen in 13.9\%, BRCA2 4.3\%, ATM 2.6\%, FLT3 1.7\%, MET 1.7\%, and VEGFA in $1 \%$ of cases. Among DNA repair genes, there was 5.2\% mutation reported in $M U T Y H$, and $1.7 \%$ in $M L H 1$ and $M S H 6$. Also, NOTCH1 alteration was found in $2.6 \%$ of cases. The alteration in hTERT promoter was seen in $1 \%$ and TERC alteration occurred in $2 \%$ of cases. 
Citation: Tehrani OS, Stephens PJ, Frampton GM, Connelly CF, Sokol ES, et al. (2018) Genetic Alterations and Tumor Mutation Burden of Poorly Differentiated Small Cell Euro-endocrine Carcinomas are Similar in Lung Lesions and Distant Metastatic Foci. J Carcinog Mutagen 9: 328. doi:10.4172/2157-2518.1000328

Page 3 of 6

\begin{tabular}{|l|l|l|l|l|}
\hline Gene & All alterations & Short variant & Copy number & Rearrangement \\
\hline TP53 & $78.30 \%$ & $75.70 \%$ & $1.70 \%$ & $0.00 \%$ \\
\hline RB1 & $62.60 \%$ & $51.30 \%$ & $9.60 \%$ & $1.70 \%$ \\
\hline PTEN & $13.90 \%$ & $7.80 \%$ & $6.10 \%$ & $0.00 \%$ \\
\hline KRAS & $9.60 \%$ & $8.70 \%$ & $0.00 \%$ & $0.00 \%$ \\
\hline CREBBP & $7.80 \%$ & $7.00 \%$ & $0.00 \%$ & $0.90 \%$ \\
\hline APC & $7.80 \%$ & $6.10 \%$ & $1.70 \%$ & $0.00 \%$ \\
\hline MLL2 & $7.00 \%$ & $7.00 \%$ & $0.00 \%$ & $0.00 \%$ \\
\hline MYC & $7.00 \%$ & $0.00 \%$ & $7.00 \%$ & $0.00 \%$ \\
\hline PIK3CA & $6.10 \%$ & $5.20 \%$ & $0.90 \%$ & $0.00 \%$ \\
\hline MUTYH & $5.20 \%$ & $5.20 \%$ & $0.00 \%$ & $0.00 \%$ \\
\hline LRP1B & $4.30 \%$ & $3.50 \%$ & $0.90 \%$ & $0.00 \%$ \\
\hline
\end{tabular}

Table 2: Common gene alterations in Small Cell Cancer of Unknown Primary (SCUP).

\section{Comparing gene alterations in SCLC and SCUP}

Difference between the frequency of more common mutations (those with frequency $>5 \%$ ) were compared between SCLC with SCUP. Significant differences were found in TP53, (12.1\% difference; $\mathrm{p}<0.001), R B 1$ (6.5\% difference; $\mathrm{p}=0.03), L R P 1 B(7.1 \%$ difference; $\mathrm{p}=0.02), P T E N$ (5.6\% difference; $\mathrm{p}=0.03$ ) and $S P T A 1$ (3.5\% difference; $\mathrm{p}=0.03)$. Findings are summarized in Table 3.

\begin{tabular}{|c|c|c|c|c|c|c|}
\hline Gene & SCLC & SCUP & $p$ value & Odds ratio & Cl $95 \%$ & z \\
\hline TP53 & $90.40 \%$ & $78.30 \%$ & $0.01 \%$ & $38.00 \%$ & $0.23-0.63$ & 3.8 \\
\hline RB1 & $69.10 \%$ & $62.60 \%$ & $3.00 \%$ & $64.00 \%$ & $0.42-0.95$ & 2.2 \\
\hline MLL2 & $11.90 \%$ & $7.00 \%$ & $12.00 \%$ & $55.00 \%$ & $0.26-1.2$ & 1.5 \\
\hline$L R P 1 B$ & $11.40 \%$ & $4.30 \%$ & $2.00 \%$ & $33.00 \%$ & $0.13-0.84$ & 2.3 \\
\hline PTEN & $8.30 \%$ & $13.90 \%$ & $3.00 \%$ & $186.00 \%$ & $1.04-3.32$ & 2.1 \\
\hline MYCL1 & $7.70 \%$ & $4.30 \%$ & $20.00 \%$ & $54.00 \%$ & $0.21-1.38$ & 1.3 \\
\hline RICTOR & $6.20 \%$ & $2.60 \%$ & $13.00 \%$ & $40.00 \%$ & $0.12-1.3$ & 1.5 \\
\hline MYC & $6.00 \%$ & $7.00 \%$ & $65.00 \%$ & $119.00 \%$ & $0.55-2.5$ & 0.4 \\
\hline CREBBP & $5.70 \%$ & $7.80 \%$ & $36.00 \%$ & $140.00 \%$ & $0.67-2.93$ & 1.4 \\
\hline SPTA1 & $5.50 \%$ & $2.00 \%$ & $3.00 \%$ & 0.29 & $0.07-1.22$ & 1.68 \\
\hline FAT1 & $5.30 \%$ & $1.00 \%$ & $6.00 \%$ & 0.14 & $0.02-1.06$ & 1.9 \\
\hline
\end{tabular}

Table 3: Common Mutations (Incidence >5\%) Small Cell Lung Cancer (SCLC) vs. Small Cell Cancer of Undetermined Primary (SCUP).

\section{Comparing gene alterations in SCLC lung lesion and distant metastatic foci}

Difference between frequency of the more common mutations (those with frequency $>5 \%$ ) were compared between most common mutations of the lung tumor vs. distant metastatic foci in SCLC. Significant differences were found only in TP53 alterations $(4.2 \%$ difference; $\mathrm{p}<0.04)$. Findings are summarized in Table 4 .

\begin{tabular}{|l|l|l|l|l|}
\hline Gene & Primary & Metastatic & p-value & Odds ratio \\
\hline
\end{tabular}

\begin{tabular}{|l|l|l|l|l|}
\hline TP53 & $93.3 \%$ & $89.1 \%$ & 0.04 & 0.58 \\
\hline RB1 & $66.0 \%$ & $70.4 \%$ & 0.19 & 1.23 \\
\hline KMT2D & $12.4 \%$ & $12.1 \%$ & 0.91 & 0.97 \\
\hline LRP1B & $9.2 \%$ & $10.1 \%$ & 0.71 & 1.10 \\
\hline PTEN & $9.0 \%$ & $6.9 \%$ & 0.35 & 0.75 \\
\hline MYCL & $7.1 \%$ & $8.3 \%$ & 0.59 & 1.18 \\
\hline
\end{tabular}


Citation: Tehrani OS, Stephens PJ, Frampton GM, Connelly CF, Sokol ES, et al. (2018) Genetic Alterations and Tumor Mutation Burden of Poorly Differentiated Small Cell Euro-endocrine Carcinomas are Similar in Lung Lesions and Distant Metastatic Foci. J Carcinog Mutagen 9: 328. doi:10.4172/2157-2518.1000328

Page 4 of 6

\begin{tabular}{|l|l|l|l|l|}
\hline CREBBP & $6.9 \%$ & $5.2 \%$ & 0.37 & 0.74 \\
\hline MYC & $6.4 \%$ & $6.0 \%$ & 0.88 & 0.93 \\
\hline PIK3CA & $5.7 \%$ & $5.2 \%$ & 0.75 & 0.89 \\
\hline FGFR1 & $5.5 \%$ & $5.7 \%$ & 1.00 & 1.04 \\
\hline RICTOR & $5.1 \%$ & $6.6 \%$ & 0.36 & 1.33 \\
\hline SPTA1 & $5.1 \%$ & $4.3 \%$ & 0.74 & 0.85 \\
\hline
\end{tabular}

Table 4: Primary vs. Metastatic Small Cell Lung Cancer (SCLC): comparing frequency of common mutations (frequency $>5 \%$ ).

Tumor mutation burden (TMB) was also compared between SCLC lung lesion and distant metastatic foci. Most common group was TMB-intermediate $(64.8 \%$ in lung lesions vs. $60.6 \%$ in distant metastatic foci), followed by TMB-low (26.9\% in lung lesions vs. $31.3 \%$ in distant metastatic foci). The least common group was TMB-high ( $8.3 \%$ in lung lesions vs. $8.0 \%$ in distant metastatic foci); There was no significant difference between TMB groups in SCLC lung lesions with distant metastatic foci $(\mathrm{p}=1)$.

\section{Concurrent mutations in SCLC}

Notably, there was significant enrichment score (ES) between TP53 and RB1 (ES=1.06; $\mathrm{p}<0.0001), T P 53$ and $M Y C(\mathrm{ES}=1.09 ; \mathrm{p}=0.02)$ and $M Y C L$ and RICTOR (ES=3.33; $\mathrm{p}=0.05)$. Other events had lower incidence and were not statistically significant. Findings are summarized in Table 5 .

\begin{tabular}{|c|c|c|c|c|c|c|c|c|}
\hline Gene 1 & Gene 2 & $\begin{array}{l}\text { gen } \\
\text { e1 }\end{array}$ & $\begin{array}{l}\text { gen } \\
\text { e2 }\end{array}$ & $\begin{array}{l}\text { Concurre } \\
\text { nce }\end{array}$ & $\begin{array}{l}\text { Expect } \\
\text { ed }\end{array}$ & $\begin{array}{l}\mathbf{R} \\
\mathbf{R}\end{array}$ & $95 \% \mathrm{Cl}$ & $\begin{array}{l}p \\
\text { value }\end{array}$ \\
\hline TP53 & $R B 1$ & 794 & 613 & 594 & 560 & $\begin{array}{l}1 . \\
06\end{array}$ & $\begin{array}{l}1.03-1.0 \\
9\end{array}$ & $\begin{array}{l}<0.000 \\
1\end{array}$ \\
\hline TP53 & PTEN & 794 & 77 & 74 & 70 & $\begin{array}{l}1 . \\
05\end{array}$ & $\begin{array}{l}0.97-1.1 \\
4\end{array}$ & 0.19 \\
\hline TP53 & MYCL1 & 794 & 66 & 55 & 60 & $\begin{array}{l}0 . \\
91\end{array}$ & $\begin{array}{l}0.80-1.0 \\
4\end{array}$ & 0.19 \\
\hline TP53 & $\begin{array}{l}\text { RICTO } \\
R\end{array}$ & 794 & 50 & 49 & 45 & $\begin{array}{l}1 . \\
08\end{array}$ & $0.98-1.2$ & 0.09 \\
\hline TP53 & MYC & 794 & 57 & 57 & 52 & $\begin{array}{l}1 . \\
09\end{array}$ & $\begin{array}{l}1.01-1.1 \\
8\end{array}$ & 0.02 \\
\hline TP53 & $\begin{array}{l}\text { CREB } \\
B P\end{array}$ & 794 & 49 & 48 & 44 & $\begin{array}{l}1 . \\
09\end{array}$ & $0.98-1.2$ & 0.09 \\
\hline TP53 & $\begin{array}{l}P I K 3 C \\
A\end{array}$ & 794 & 44 & 41 & 40 & $\begin{array}{l}1 . \\
02\end{array}$ & $\begin{array}{l}0.90-1.1 \\
5\end{array}$ & 0.69 \\
\hline$R B 1$ & PTEN & 613 & 77 & 56 & 54 & $\begin{array}{l}1 . \\
03\end{array}$ & $\begin{array}{l}0.84-1.2 \\
6\end{array}$ & 0.72 \\
\hline RB1 & MYCL1 & 613 & 66 & 51 & 46 & $\begin{array}{l}1 . \\
11\end{array}$ & $0.9-1.36$ & 0.32 \\
\hline$R B 1$ & $\begin{array}{l}\text { RICTO } \\
R\end{array}$ & 613 & 50 & 36 & 35 & $\begin{array}{l}0 . \\
98\end{array}$ & $\begin{array}{l}0.77-1.2 \\
6\end{array}$ & 0.91 \\
\hline$R B 1$ & MYC & 613 & 57 & 38 & 40 & $\begin{array}{l}0 . \\
95\end{array}$ & $\begin{array}{l}0.74-1.2 \\
1\end{array}$ & 0.68 \\
\hline$R B 1$ & $\begin{array}{l}\text { CREB } \\
B P\end{array}$ & 613 & 49 & 39 & 34 & $\begin{array}{l}1 . \\
14\end{array}$ & $\begin{array}{l}0.90-1.4 \\
4\end{array}$ & 0.25 \\
\hline
\end{tabular}

\begin{tabular}{|c|c|c|c|c|c|c|c|c|}
\hline$R B 1$ & $\begin{array}{l}P I K 3 C \\
A\end{array}$ & 613 & 44 & 27 & 31 & $\begin{array}{l}0 . \\
87\end{array}$ & $\begin{array}{l}0.64-1.7 \\
9\end{array}$ & 0.37 \\
\hline PTEN & MYCL1 & 77 & 66 & 7 & 5 & $\begin{array}{l}1 . \\
4\end{array}$ & $\begin{array}{l}0.46-4.1 \\
9\end{array}$ & 0.54 \\
\hline PTEN & $\begin{array}{l}\text { RICTO } \\
R\end{array}$ & 77 & 50 & 8 & 4 & 2 & $\begin{array}{l}0.64-6.2 \\
1\end{array}$ & 0.23 \\
\hline PTEN & MYC & 77 & 57 & 10 & 5 & 2 & $0.73-5.4$ & 0.18 \\
\hline PTEN & $\begin{array}{l}\text { CREB } \\
B P\end{array}$ & 77 & 49 & 4 & 4 & 1 & $\begin{array}{l}0.27-3.7 \\
7\end{array}$ & 1 \\
\hline PTEN & $\begin{array}{l}P I K 3 C \\
A\end{array}$ & 77 & 44 & 8 & 3 & $\begin{array}{l}2 . \\
67\end{array}$ & $0.74-9.5$ & 0.13 \\
\hline MYCL1 & $\begin{array}{l}\text { RICTO } \\
R\end{array}$ & 66 & 50 & 10 & 3 & $\begin{array}{l}3 . \\
33\end{array}$ & $\begin{array}{l}0.97-11 . \\
4\end{array}$ & 0.05 \\
\hline MYCL1 & MYC & 66 & 57 & 3 & 4 & $\begin{array}{l}0 . \\
75\end{array}$ & $1.18-3.2$ & 0.69 \\
\hline MYCL1 & $\begin{array}{l}\text { CREB } \\
B P\end{array}$ & 66 & 49 & 1 & 3 & $\begin{array}{l}0 . \\
33\end{array}$ & $\begin{array}{l}0.04-3.0 \\
9\end{array}$ & 0.33 \\
\hline MYCL1 & $\begin{array}{l}\text { PIK3C } \\
A\end{array}$ & 66 & 44 & 2 & 3 & $\begin{array}{l}0 . \\
67\end{array}$ & $\begin{array}{l}0.12-3.7 \\
8\end{array}$ & 0.64 \\
\hline $\begin{array}{l}\text { RICTO } \\
R\end{array}$ & MYC & 50 & 57 & 8 & 3 & $\begin{array}{l}2 . \\
67\end{array}$ & $0.74-9.5$ & 0.13 \\
\hline $\begin{array}{l}\text { RICTO } \\
R\end{array}$ & $\begin{array}{l}\text { CREB } \\
B P\end{array}$ & 50 & 49 & 0 & 2 & $\begin{array}{l}0 . \\
2\end{array}$ & $0.01-4$ & 0.29 \\
\hline $\begin{array}{l}\text { RICTO } \\
R\end{array}$ & $\begin{array}{l}P I K 3 C \\
A\end{array}$ & 50 & 44 & 3 & 2 & $\begin{array}{l}1 . \\
27\end{array}$ & $\begin{array}{l}0.22-7.2 \\
6\end{array}$ & 0.79 \\
\hline MYC & $\begin{array}{l}\text { CREB } \\
B P\end{array}$ & 57 & 49 & 2 & 3 & $\begin{array}{l}0 . \\
67\end{array}$ & $\begin{array}{l}0.12-3.8 \\
2\end{array}$ & 0.65 \\
\hline MYC & $\begin{array}{l}\text { PIK3C } \\
A\end{array}$ & 57 & 44 & 6 & 2 & 3 & $\begin{array}{l}0.64-14 . \\
06\end{array}$ & 0.16 \\
\hline $\begin{array}{l}\text { CREB } \\
B P\end{array}$ & $\begin{array}{l}P I K 3 C \\
A\end{array}$ & 49 & 44 & 1 & 2 & $\begin{array}{l}0 . \\
5\end{array}$ & $\begin{array}{l}0.05-5.3 \\
2\end{array}$ & 0.56 \\
\hline
\end{tabular}

Table 5: Incidence of Concurrent Common Mutations in Small Cell Lung Cancer (SCLC).

\section{Discussion}

Poorly differentiated small cell neuroendocrine cancers are a major problem in oncology. The pathways and mechanisms involved in the development of these cancers have remained unclear. Multiple studies have reported various mutations in cell lines, xeno-grafts and primary human tumors with limited or whole genome sequencing $[10,11]$. Besides the high prevalence of concurrent loss-of-function of TP53 and $R B 1$, there were frequent alterations of genes involved in transmembrane signaling and transcription machinery, including chromosome remodeling, histone modifications, and transcription factors. ARID1A is involved in SWItch/Sucrose Non-Fermentable (SWI/SNF) chromosome remodeling complex [26]. TP53, KMT2D (coding for MLL2) and CREBBP code proteins that are involved in histone acetylation, $\mathrm{Rb} 1$ protein represses transcription through interaction with histone deacetylase [27-29]. In addition, there are structural homology between the SWI/SNF complex B/MDM2 domain and MDM2 protein [30], possibly interacting with p53 protein. Inactivation of Rb1 leads to activation of transcription factor E2F [31]. 
Citation: Tehrani OS, Stephens PJ, Frampton GM, Connelly CF, Sokol ES, et al. (2018) Genetic Alterations and Tumor Mutation Burden of Poorly Differentiated Small Cell Euro-endocrine Carcinomas are Similar in Lung Lesions and Distant Metastatic Foci. J Carcinog Mutagen 9: 328. doi:10.4172/2157-2518.1000328

Page 5 of 6

MYC and MYCL are other transcription factors frequently altered in this study. NOTCH protein alterations lead to changes in chromosome remodeling [32]. In addition, altered receptor tyrosine kinases (FGFR and EGFR) and PIK3CA, PTEN, AKT, RICTOR and KRAS gene show altered PIK3CA/PTENIAKT and RAS/MEK signaling pathways in these tumors (Supplemental figure).

Multiple potentially targetable genetic alterations were identified. It should be noted that an alteration may not be readily targetable or applicable in the clinic. Potential as therapeutic alteration also depends on what domain of the protein is altered, whether there is enough gene expression, role of the altered gene as a driver mutation, availability of effective medication for specific mutations, accessibility of the altered protein domains, among many important factors. Genetic alterations with available targeted therapies were frequently found. The most common alteration was PIK3CA/PTEN/AKT pathway, confirming prior reports $[33,34]$. NOTCH alterations were frequently seen in both SCLC and SCUP, suggesting their potential role in the future targeted therapies. NOTCH family alterations CREBBP, EP300, TP73, RBL1, and $R B L 2$ have been reported to be mutually exclusive in SCLC [12].

Despite prior reports of high hTERT expression in small cell neuroendocrine cancers [35-37], current study did not find a high rate of alteration in $h T E R T$ promoter. Prior studies have also reported high rate of $h T E R T$ promoter mutation in Merkel cell tumors, which is an aggressive small cell neuroendocrine cancer of skin [37]. Similarly, another study reported low rate of $h T E R T$ promoter mutation in small cell neuroendocrine cancer, except for those in the bladder [15]. Cell culture studies have shown that hTERT expression is needed for continued cell growth and overcoming crisis in cells with disrupted $p 53$ and $R b 1$ pathways [38]. Additionally, SWI/SNF complex has been shown to be involved in expression of hTERT [39]. These findings suggest that different mechanisms can be involved in hTERT expression in tumors of different origins.

Current study also reported frequent alteration of $K M T 2 D(12.4 \%)$. The prior studies reported that inactivation of this gene is associated with decreased proliferation of malignant cells and improved patient survival [27,40-43]. If similar correlation exists in SCLC, then there is a potential to target this gene as a therapeutic target.

High tumor mutation burden (TMB-high) was not a common finding and there was a low incidence of the genetic alteration in the genes associated with microsatellite instability ( $M S H 2, M S H 6, M L H 1$, PMS2), resembling other solid tumors [25]. Most of the patients with significant microsatellite instability (MSI-high) have high tumor mutation burden (TMB-high) and is associated with response to immunotherapy $[25,44,45]$. Low incidence of high TMB has been reported in previous SCLC studies [46]. Low incidence of high TMB in these cancers is happening despite high association with smoking and TP53, which is known as guardian of DNA. Interestingly, it seems that survival (progression free survival and overall survival) and not response rate, correlate with TMB in SCLC patients treated with nivolumab alone or combined with ipilimumab, does not correlate with TMB [47].

Notably, there was significantly enriched co-occurrence of TP53 and $R B 1$ alterations, suggesting that their concurrent alteration is crucial in this type of cancer. Despite frequent alteration of the genes involved in membrane signaling and transcription machinery, these alterations did not show enriched co-occurrence. The independent alterations of the genes involved in parallel pathways and common mechanisms provide variety of mechanisms for aggressive, resistant and relapsing nature of
SCLC and SCUP. It also identifies multiple new potential therapeutic targets and pathways, which necessitate further evaluation and clinical trials in these cancers. In addition, similar gene alterations and tumor mutation burden were found in the SCLC lung lesions and distant metastatic foci [48-50]. It seems that the presence of TP53 and $R B 1$ alteration is preserved in combined small cell lung cancer and nonsmall cell lung cancer [51].

\section{Conclusion}

This study showed similar genetic alteration and tumor mutation burden in the lung lesions and in distant metastatic foci. TP53 and RB1 were the frequently altered concurrently.

\section{References}

1. Huang R, Wei Y, Hung RJ, Liu G, Su L, et al. (2015) Associated Links Among Smoking, Chronic Obstructive Pulmonary Disease, and Small Cell Lung Cancer: A Pooled Analysis in the International Lung Cancer Consortium. EBioMedicine 2: 1677-1685.

2. Pesch B, Kendzia B, Gustavsson P, Jöckel K-H, Johnen G, et al.(2012) Cigarette smoking and lung cancer--relative risk estimates for the major histological types from a pooled analysis of case-control studies. Int J Cancer 131: 1210-1219.

3. Engeland A, Haldorsen T, Andersen A, Tretli S (1996) The impact of smoking habits on lung cancer risk: 28 years' observation of 26,000 Norwegian men and women. Cancer Causes Control 7: 366-376.

4. Freedman ND, Leitzmann MF, Hollenbeck AR, Schatzkin A, Abnet CC (2008) Cigarette smoking and subsequent risk of lung cancer in men and women: analysis of a prospective cohort study. Lancet Oncol 9: 649-656.

5. Sahmoun AE, Case LD, Santoro TJ, Schwartz GG (2005) Anatomical distribution of small cell lung cancer: effects of lobe and gender on brain metastasis and survival. Anticancer Res 25: 1101-1108.

6. Abdel-Rahman O (2017) Changing epidemiology of elderly small cell lung cancer patients over the last 40 years; a SEER database analysis. Clin Respir J 12: 1093-1099.

7. Adelstein DJ, Tomashefski JF, Snow NJ, Horrigan TP, Hines JD (1986) Mixed small cell and non-small cell lung cancer. Chest 89: 699-704.

8. La Rosa S, Marando A, Sessa F, Capella C (2012) Mixed Adenoneuroendocrine Carcinomas (MANECs) of the Gastrointestinal Tract: An Update. Cancers 4: 11-30.

9. Wang W, Epstein JI (2008) Small cell carcinoma of the prostate. A morphologic and immunohistochemical study of 95 cases. Am J Surg Pathol 32: 65-71.

10. Ross JS, Wang K, Elkadi OR, Tarasen A, Foulke L, et al. (2014) Nextgeneration sequencing reveals frequent consistent genomic alterations in small cell undifferentiated lung cancer. J Clin Pathol 67: 772-776.

11. Rudin CM, Durinck S, Stawiski EW, Poirier JT, Modrusan Z, et al. (2012) Comprehensive genomic analysis identifies SOX2 as a frequently amplified gene in small-cell lung cancer. Nat Genet 44: 1111-1116.

12. George J, Lim JS, Jang SJ, Cun Y, Ozretić L, et al. (2015) Comprehensive genomic profiles of small cell lung cancer. Nature 524: 47-53.

13. Liu D, Xu X, Wen J, Xie L, Zhang J, et al. (2018) Integrated Genome-Wide Analysis of Gene Expression and DNA Copy Number Variations Highlights Stem Cell-Related Pathways in Small Cell Esophageal Carcinoma. Stem Cells Int 2018: 3481783

14. Yachida S, Vakiani E, White CM, Zhong Y, Saunders T, et al. (2012) Small cell and large cell neuroendocrine carcinomas of the pancreas are genetically similar and distinct from well-differentiated pancreatic neuroendocrine tumors. Am J Surg Pathol 36: 173-184.

15. Zheng X, Zhuge J, Bezerra SM, Faraj SF, Munari E, et al. (2014) High frequency of TERT promoter mutation in small cell carcinoma of bladder but not in small cell carcinoma of other origins. J Hematol OncolJ Hematol Oncol 7: 47. 
Citation: Tehrani OS, Stephens PJ, Frampton GM, Connelly CF, Sokol ES, et al. (2018) Genetic Alterations and Tumor Mutation Burden of Poorly Differentiated Small Cell Euro-endocrine Carcinomas are Similar in Lung Lesions and Distant Metastatic Foci. J Carcinog Mutagen 9: 328. doi:10.4172/2157-2518.1000328

Page 6 of 6

16. Karanian-Philippe M, Velasco V, Longy M, Floquet A, Arnould L, et al (2015) SMARCA4 (BRG1) loss of expression is a useful marker for the diagnosis of ovarian small cell carcinoma of the hypercalcemic type (ovarian rhabdoid tumor): a comprehensive analysis of 116 rare gynecologic tumors, 9 soft tissue tumors, and 9 melanomas. Am J Surg Pathol 39: 1197-1205.

17. Heenan PJ, Cole JM, Spagnolo DV (1990) Primary cutaneous neuroendocrine carcinoma (Merkel cell tumor). An adnexal epithelial neoplasm. Am J Dermatopathol 12: 7-16.

18. Higaki-Mori H, Kuwamoto S, Iwasaki T, Kato M, Murakami I, et al. (2012) Association of Merkel cell polyomavirus infection with clinicopathological differences in Merkel cell carcinoma. Hum Pathol 43: 2282-2291.

19. Anbazhagan R, Tihan T, Bornman DM, Johnston JC, Saltz JH, et al. (1999) Classification of small cell lung cancer and pulmonary carcinoid by gene expression profiles. Cancer Res 59: 5119-5122.

20. Iwakawa R, Takenaka M, Kohno T, Shimada Y, Totoki Y, et al. (2013) Genome-wide identification of genes with amplification and/or fusion in small cell lung cancer. Genes Chromosomes Cancer 52: 802-816.

21. Kim YH, Girard L, Giacomini CP, Wang P, Hernandez-Boussard T, et al. (2006) Combined microarray analysis of small cell lung cancer reveals altered apoptotic balance and distinct expression signatures of MYC family gene amplification. Oncogene 25: 130-138.

22. Frampton GM, Fichtenholtz A, Otto GA, Wang K, Downing SR, et al. (2013) Development and validation of a clinical cancer genomic profiling test based on massively parallel DNA sequencing. Nat Biotechnol 31: 1023-1031.

23. Johnson DB, Frampton GM, Rioth MJ, Yusko E, Xu Y, et al. (2016) Targeted Next Generation Sequencing Identifies Markers of Response to PD-1 Blockade. Cancer Immunol Res 4: 959-967.

24. Rosenberg JE, Hoffman-Censits J, Powles T, van der Heijden MS, Balar $\mathrm{AV}$, et al. (2016) Atezolizumab in patients with locally advanced and metastatic urothelial carcinoma who have progressed following treatment with platinum-based chemotherapy: a single-arm, multicentre, phase 2 trial. Lancet Lond Engl 387: 1909-1920.

25. Chalmers ZR, Connelly CF, Fabrizio D, Gay L, Ali SM, et al. (2017) Analysis of 100,000 human cancer genomes reveals the landscape of tumor mutational burden. Genome Med 9: 34

26. Guan B, Wang T-L, Shih I-M (2011) ARID1A, a factor that promotes formation of SWI/SNF-mediated chromatin remodeling, is a tumor suppressor in gynecologic cancers. Cancer Res 71: 6718-6727.

27. Guo C, Chen LH, Huang Y, Chang C-C, Wang P, et al. (2013) KMT2D maintains neoplastic cell proliferation and global histone $\mathrm{H} 3$ lysine 4 monomethylation. Oncotarget 4: 2144-2153.

28. Luo RX, Postigo AA, Dean DC (1998) Rb interacts with histone deacetylase to repress transcription. Cell 92: 463-473.

29. Robertson KD, Ait-Si-Ali S, Yokochi T, Wade PA, Jones PL, et al. (2000) DNMT1 forms a complex with Rb, E2F1 and HDAC1 and represses transcription from E2F-responsive promoters. Nat Genet 25: 338-342.

30. Bennett-Lovsey R, Hart SE, Shirai H, Mizuguchi K (2002) The SWIB and the MDM2 domains are homologous and share a common fold Bioinforma Oxf Engl 18: 626-630.

31. Cobrinik D (2005) Pocket proteins and cell cycle control. Oncogene 24 2796-2809.

32. Mourikis P, Lake RJ, Firnhaber CB, DeDecker BS (2010) Modifiers of notch transcriptional activity identified by genome-wide RNAi. BMC Dev Biol 10: 107.

33. Umemura S, Mimaki S, Makinoshima H, Tada S, Ishii G, et al. (2014) Therapeutic priority of the $\mathrm{PI} 3 \mathrm{~K} / \mathrm{AKT} / \mathrm{mTOR}$ pathway in small cell lung cancers as revealed by a comprehensive genomic analysis. J Thorac Oncol Off Publ Int Assoc Study Lung Cancer 9: 1324-1331.
34. Yokomizo A, Tindall DJ, Drabkin H, Gemmill R, Franklin W, et al. (1998) PTEN/MMAC1 mutations identified in small cell, but not in non-small cell lung cancers. Oncogene 17: 475-479.

35. Gómez-Román JJ, Romero AF, Castro LS, Nieto EH, Fernández-Luna JL et al. (2000) Telomerase activity in pulmonary neuroendocrine tumors: correlation with histologic subtype (MS-0060). Am J Surg Pathol 24: 417421.

36. Hiyama K, Hiyama E, Ishioka S, Yamakido M, Inai K, et al. (1995) Telomerase activity in small-cell and non-small-cell lung cancers. J Natl Cancer Inst 87: 895-902.

37. Xie H, Liu T, Wang N, Björnhagen V, Höög A, et al. (2014) TERT promoter mutations and gene amplification: promoting TERT expression in Merkel cell carcinoma. Oncotarget 5: 10048-10057.

38. Hahn WC, Counter CM, Lundberg AS, Beijersbergen RL, Brooks MW, et al. (1999) Creation of human tumour cells with defined genetic elements. Nature 400: 464-468

39. Wu S, Ge Y, Huang L, Liu H, Xue Y, et al. (2014) BRG1, the ATPase subunit of SWI/SNF chromatin remodeling complex, interacts with HDAC2 to modulate telomerase expression in human cancer cells. Cell Cycle 13: 2869-2878.

40. Simbolo M, Mafficini A, Sikora KO, Fassan M, Barbi S, et al. (2017) Lung neuroendocrine tumours: deep sequencing of the four World Health Organization histotypes reveals chromatin-remodelling genes as major players and a prognostic role for TERT, RB1, MEN1 and KMT2D. J Pathol 241: 488-500.

41. Dawkins JBN, Wang J, Maniati E, Heward JA, Koniali L, et al. (2016) Reduced Expression of Histone Methyltransferases KMT2C and KMT2D Correlates with Improved Outcome in Pancreatic Ductal Adenocarcinoma. Cancer Res 76: 4861-4871.

42. Kim J-H, Sharma A, Dhar SS, Lee S-H, Gu B, et al. (2014) UTX and MLL4 coordinately regulate transcriptional programs for cell proliferation and invasiveness in breast cancer cells. Cancer Res 74: 17051717.

43. Mo R, Rao SM, Zhu Y-J (2006) Identification of the MLL2 complex as a coactivator for estrogen receptor alpha. J Biol Chem 281: 15714-15720.

44. Carbone DP, Reck M, Paz-Ares L, Creelan B, Horn L, et al. (2017) FirstLine Nivolumab in Stage IV or Recurrent Non-Small-Cell Lung Cancer. N Engl J Med 376: 2415-2426.

45. Hellmann MD, Ciuleanu T-E, Pluzanski A, Lee JS, Otterson GA, et al. (2018) Nivolumab plus Ipilimumab in Lung Cancer with a High Tumor Mutational Burden. N Engl J Med 378: 2093-2104.

46. Boumber Y (2018) Tumor mutational burden (TMB) as a biomarker of response to immunotherapy in small cell lung cancer. J Thorac Dis 10: 4689-4693.

47. Hellmann MD, Callahan MK, Awad MM, Calvo E, Ascierto PAet al (2018) Tumor Mutational Burden and Efficacy of Nivolumab Monotherapy and in Combination with Ipilimumab in Small-Cell Lung Cancer. Cancer Cell 33: 853-861.e4.

48. Vakiani E, Janakiraman M, Shen R, Sinha R, Zeng Z, et al. (2012) Comparative genomic analysis of primary versus metastatic colorectal carcinomas. J Clin Oncol 30: 2956-2962.

49. Bertucci F, Finetti P, Guille A, Adélaïde J, Garnier S, et al. (2016) Comparative genomic analysis of primary tumors and metastases in breast cancer. Oncotarget 7: 27208-27219.

50. Bambury RM, Bhatt AS, Riester M, Pedamallu CS, Duke F, et al. (2015) DNA copy number analysis of metastatic urothelial carcinoma with comparison to primary tumors. BMC Cancer 15: 242.

51. Lin MW, Su KY, Su TJ, Chang CC, Lin JW, et al. (2018) Clinicopathological and genomic comparisons between different histologic components in combined small cell lung cancer and non-small cell lung cancer. Lung Cancer Amst Neth 125: 282-290. 